Agric, Biol. Chem., 42 (7), 1315 1321, 1978

\title{
Products of Peroxidase Catalyzed Oxidation of Indolyl-3-acetic Acid
}

\author{
Yoshikatsu Suzuki and Akira KaWARADA \\ The Institute of Physical and Chemical Research, \\ Wako-shi, Saitama 351, Japan \\ Received December 5, 1977
}

\begin{abstract}
Six new products of oxidation of indolyl-3-acetic acid catalyzed by horseradish peroxidase were isolated, along with four known ones, 3-hydroxymethyloxindole (1), 3-methyleneoxindole (2), indolyl-3-aldehyde (4), and 3,3-diindolylmethane (10). Based on spectroscopic and chemical evidence, the new products were identified as 3-acetoxyindole (3), 3-(indol-3-ylmethyl)oxindole (6), 3-[(2-indol-3-ylmethyl)indol-3-ylmethyl]oxindole (9), the 3-hydroxymethyl compounds of 6 and 9 (5 and 7), and 2-(indol-3-ylmethyl)indolyl-3-acetic acid (8), respectively.
\end{abstract}

The presence of peroxidase-like enzyme systems catalyzing the oxidative inactivation of indolyl-3-acetic acid (IAA) in higher plants has long recognized. Recently two IAA oxidases been lacking peroxidase activities have also been reported. To clarify the physiological significance of in vivo IAA inactivation by these enzyme systems, much effor ${ }^{11}$ has been devoted to the study of in vitro oxidative IAA decomposition by horseradish peroxidase (HRP) or by other systems, as well as of in vivo metabolisms in plants. Hinman and Lang' proposed a reaction scheme for the oxidation of IAA by HRP in which IAA is converted to either indolyl-3-aldehyde or 3-methyleneoxindole, via a common intermediate to both. In a corn IAA oxidase system, another pathway that 3-hydroperoxymethylindole is a key intermediate in oxindole formation has also been proposed. ${ }^{3)}$ However, these proposals have not fully substantiated because the formation of any of the hypothetical key intermediates have not been confirmed. We have recently reported the isolation of oxindolyl- and dioxindolyl-3-acetic acids from rice bran ${ }^{4}$ and matured corn seeds, ${ }^{5)}$ which seemed to suggest the possibility of the presence of a different oxidative route of IAA to dioxindoles via oxindoles, at least in these plants. A part of a similar route has been found in a fungus, Hygrophorous conicus, in which an oxidase system converts IAA to oxindolyl-3-acetic $\operatorname{acid}^{6)}$
The previous works on enzymatic oxidation of IAA have not been very thorough in regard to the product identification; 3-methyleneoxindole, ${ }^{7 /}$ indolyl-3-aldehyde, ${ }^{8}$ 3,3-diindolylmethane, 3-methylene-indolenine, and the indolylmethyl ester of indolyl-3-acetic acid have been ultimately confirmed and 3-hyroxymethyloxindole ${ }^{9,2}>$ has been tentatively identified. This paper describes a more extended isolation and identification of in vitro HRP oxidation products of IAA, carried out to provide basis for the establishment of the oxidation routes and mechanism.

\section{Isolation of enzymatic oxidation products of} IAA with HRP

The course of the enzymatic oxidation of IAA has been known highly dependent on the concentration of each reaction component, i.e., substrate, enzyme, cofactor, and buffer, as well as $\mathrm{pH}$ of the medium. The main product of reaction with IAA concentration below $2 \times 10^{-4} \mathrm{M}$ is known to be 3-methyleneoxindole, while it is an unidentified neutral indole with IAA concentration up to $10^{-2} \mathrm{M}^{23}$ Thus, the initial IAA concentration of $2 \times$ $10^{-4} \mathrm{M}$ that permits possibly straightforward enzymatic reaction was used in the present study.

The UV spectral change of the reaction is shown in Fig. 1. During the first 10 min the rapid decrease of the indole absorption (280 $288 \mathrm{~nm}$ ) with simultaneous increase of the 


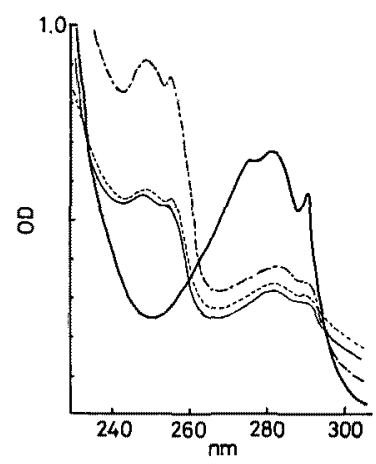

FIG. 1. UV Spectra of the Ether Extract of the IAA/HRR Reaction Mixture Taken at Intervals. $(-0,-\cdot-\cdot 10,-15, \cdots-\cdots 30 \mathrm{~min})$.

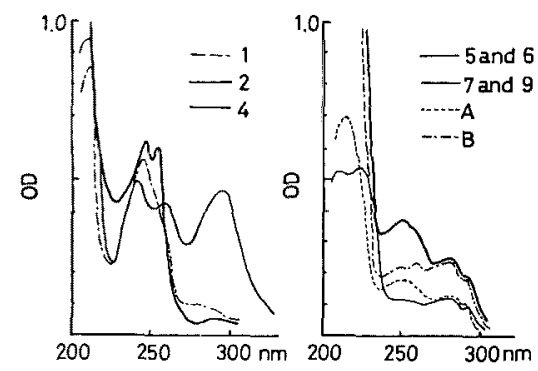

FIG. 2. UV Spectra of IAA Oxidation Prodects in $\mathrm{MeOH}$.

A: IAA and oxindolyl-3-acetic acid $(1 ; 1), \mathrm{B}:(2 ; 1)$.

Table I. Yields and $R f$ Values of Products

\begin{tabular}{cccc}
\hline \multirow{2}{*}{ Product $^{a}$} & Yield (mg) & \multicolumn{2}{c}{$R f$ Value $^{b}$} \\
\cline { 2 - 4 } & & $\mathrm{a}$ & $\mathrm{b}$ \\
\hline $\mathbf{1}$ & $80^{c}$ & 0.42 & 0.15 \\
$\mathbf{2}$ & $32^{c}$ & 0.62 & 0.43 \\
$\mathbf{3}$ & 5.0 & 0.69 & 0.62 \\
$\mathbf{4}$ & 8.0 & 0.49 & 0.33 \\
$\mathbf{5}$ & 8.0 & 0.44 & 0.19 \\
$\mathbf{6}$ & 19.0 & 0.61 & 0.35 \\
$\mathbf{7}$ & 4.2 & 0.51 & 0.27 \\
$\mathbf{8}$ & 4.0 & 0.62 & 0.12 \\
$\mathbf{9}$ & 9.1 & 0.62 & 0.44 \\
10 & 5.4 & 0.73 & 0.63 \\
\hline
\end{tabular}

a The sum of the substrate added corresponds to $420 \mathrm{mg}$ as free IAA.

${ }^{b}$ a: $\mathrm{CHCl}_{3}-\mathrm{EtOAc}-\mathrm{HCO}_{2} \mathrm{H}$ (35: 55: 10), b: $\mathrm{MeOH}-\mathrm{CHCl}_{3}$ (7:93).

- Yields of crude materials.

oxindole absorption ( $250 \mathrm{~nm}$ region) was observed, and the decrease of the former absorption indicated the consumption of about a half of the substrate at this point. The reaction slowed down after $10 \mathrm{~min}$, and came to virtual standstill after $15 \mathrm{~min}$. An incubation time of $30 \mathrm{~min}$ for a large scale reaction was therefore selected in order to minimize the possibility of further reactions.

A preparative scale reaction was carried out in a similar manner. Ten products which are summarized in the Table could be separated by gel filtration on Sephadex LH 20, followed by either preparative thin-layer chromatography (TLC) on silica gel and/or crystallization.

\section{Identification and structural elucidation}

Ten products thus isolated may be classified into the following 5 groups on the basis of their UV spectral features; 1) oxindoles: 1 and 2,2 ) indoles: 3,8 , and 10,3 ) oxindoles with one indole unit: 5 and 6,4 ) oxindoles with two indole units: 7 and 9,5) others: 4. Among these ten, two were readily identified by their characteristic UV spectra as 3-methyleneoxindole (2) and indolyl-3-aldehyde (4) which have been established as the products in IAAperoxidase reactions. $^{7 \sim 8)}$

\section{1) Group 1 (1 and 2)}

Product $1, m / e 163\left(\mathrm{M}^{+}\right)$, was identified as 3-hydroxymethyloxindole ${ }^{2)}$ by the ready change of 1 to 3-methyleneoxindole (2). This substance has been reported first as an inhibitor of cell growth in photo-oxidation products of IAA $^{93}$ and subsequently as an immediate precursor leading to 2 in the HRP oxidation of IAA. ${ }^{2}$ However, only a tentative structure

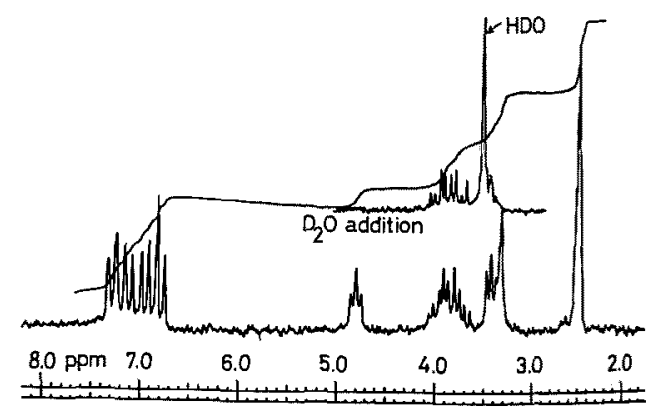

FIG. 3. PMR Spectrum of 3-Hydroxymethyloxindole (1) $\left(\mathrm{CD}_{3} \mathrm{SOCD}_{3}, 100 \mathrm{MHz}\right)$. 
for this substance has been presented because of its insufficient purity due to its labileness. The PMR spectrum of 1 , shown in Fig. 3, ultimately confirmed this.

\section{2) Group $2(3,8$, and 10)}

Products 3,8 , and 10, the latter two of which turned deep red during purification procedure, showed exclusively an UV absorption characteristic to indole compounds. The absorption intensities showed the presence of single indole chromophore in one molecules of $\mathbf{3}$, and two, in 8 and $\mathbf{1 0}$.

Product 3, m/e $175\left(\mathrm{M}^{+}\right)$, gave a singlet $(3 \mathrm{H})$ at $\delta 2.30$ that is ascribed to the methyl of an acetyl group, a multiplet $(5 \mathrm{H}$, aromatic protons) at $\delta 7.00 \sim 7.50$ in the PMR spectrum, and also an enolacetate band $\left(\nu 1750 \mathrm{~cm}^{-1}\right)$ in the IR spectrum. These data suggested that 3 is 3-acetoxyindole, being identified by comparison with an authentic sample.

Product 8, m/e $304\left(\mathrm{M}^{+}, \quad \mathrm{C}_{19} \mathrm{H}_{16} \mathrm{O}_{2} \mathrm{~N}_{2}\right)$, showed a carbonyl band $\left(\nu 1700 \mathrm{~cm}^{-1}\right)$ in the IR spectrum. In addition the fragment ions at $m / e 259\left(\mathrm{M}-\mathrm{CO}_{2} \mathrm{H}\right)$ and $245\left(\mathrm{M}-\mathrm{CH}_{2} \mathrm{CO}_{2} \mathrm{H}\right)$ in the MS spectrum indicated the presence of the partial structure of $-\mathrm{CH}_{2} \mathrm{CO}_{2} \mathrm{H}$, the methylene signal of which was observed as a singlet at $\delta 3.74$ in the PMR spectrum. The presence of this group was also supported by the MS data of the methyl ester (by diazomethane) and of the reduction product (by lithium aluminum hydride) of 8 . The PMR spectrum showed another singlet $(2 \mathrm{H})$ at $\delta 4.25$ ascribed to the methylene bearing two olefins. These data are consistent with an indolyl-3-acetic acid with an indolylmethyl substituent, which is attached to one of available positions excluding the 1-position of the indole ring, since two NH were observed in the PMR spectrum. The position of the attached methylene group, although not fully evidenced, is probably between the C-2 of IAA and the C-3 of indole, on the basis of its probable formation mechanism discussed later.

Product 10, m/e $246\left(\mathrm{M}^{+}\right)$, was identified as 3,3-diindolylmethane from the MS and PMR data. This compound has been reported as the reaction product in a corn IAA oxidase system..$^{31}$

\section{3) Group 3 (5 and 6)}

Product 5 and 6 have characteristic UV absorption presumably consisting of bands of indole and oxindole chromophores, as shown in Fig. 2. In fact an UV spectrum of an equimolar mixture solution of IAA and oxindolyl3-acetic acid (Spectrum A) showed close resemblance to that of 5 or 6 . In addition, the absorption intentities showed the presence of each one unit of indole and oxindole chromophore in either of the molecules.

Product 6, m/e $262\left(\mathrm{M}^{+}\right)$, showed carbonyl and $\mathrm{NH}$ bands $\left(\nu 1700\right.$ and $\left.3400 \mathrm{~cm}^{-1}\right)$ in the IR spectrum. The PMR spectrum gave signals of an $A B X$ type of splitting at $\delta 3.10$ and 3.45, and 3.78 , and a multiplet $(9 \mathrm{H}$, aromatic protons) at $\delta 6.70 \sim 7.60$. These data suggested 3-(indol-3-ylmethyl)oxindole. The fragment ion at $m / e 130$ (base peak) is consistent with this structure. Reduction of $\mathbf{6}$ (by lithium aluminum hydride) afforded the expected substance 10.

Product 5, m/e $292\left(\mathrm{M}^{+}, \mathrm{C}_{18} \mathrm{H}_{16} \mathrm{O}_{2} \mathrm{~N}_{2}\right)$, gave signals of an $A B$ type quartet centered at $\delta 3.15$, a singlet $(2 \mathrm{H})$ at $\delta 3.78$, and a multiplet $(9 \mathrm{H}$, aromatic protons) at $\delta 6.50 \sim 7.50$ in the PMR spectrum. The singlet at $\delta 3.78$, which shifted to an $A B$ type quartet centered at $\delta 4.59$ when diacetylated, was assigned as the methylene bearing a hydroxy group. These data are consistent with the 3-hydroxymethyl derivative of 6 . The presence of the fragment ions at $m / e 262\left(\mathrm{M}-\mathrm{CH}_{2} \mathrm{O}\right)$ and $130\left(\mathrm{C}_{9} \mathrm{H}_{8} \mathrm{~N}\right.$, base peak) supported the elucidated structure.

\section{4) Group 4 (7 and 9)}

Products 7 and 9 have a characteristic UV absorption as shown in Fig. 2, that is similar to that of a synthetic 2:1 mixture of IAA and oxindolyl-3-acetic acid. Also the absorption intensities showed the presence of two units of indole and one unit of oxindole chromophores in its molecule.

Product 9, m/e $391\left(\mathrm{M}^{+}, \mathrm{C}_{26} \mathrm{H}_{21} \mathrm{ON}_{3}\right)$, gave an $A B X$ type of splitting at $\delta 3.14,3.64$, and 3.82 similar to those of 6 , and a singlet $(2 \mathrm{H})$ at $\delta 4.14$ that was assigned as the methylene bearing two olefins. These suggested 9 as a 
3-(indol-3-ylmethyl)oxindole (6) with an indolylmethyl substituent. In the MS spectrum of 9, the presence of the fragment ions at $\mathrm{m} / \mathrm{e}$ $259(\mathrm{M}-132)$ and $260(\mathrm{M}-131)$ indicated that the substitution of the indole residue occurs on the indole ring of 6 . If it does on the oxindole side, the fragment ions at $m / e 261$ (M130) and $262(\mathrm{M}-129)$ will be expected. The assumption that the linkage is at the $\mathrm{C}-2$ of 6 seems to be most probable, considering the usual high reactivity at this position in indole ring.

Product $7, m / e 421\left(\mathrm{M}^{+}\right)$, gave signals of $A B$ type quartet centered at $\delta 3.40$, a singlet at $\delta 4.00(2 \mathrm{H})$ similar to those of 5 , and a singlet at $\delta 4.10(2 \mathrm{H})$ assigned to the methylene bearing two olefins. The fragment ions at $m / e 391$ and 259 corresponding to $\mathrm{M}-\mathrm{CH}_{2} \mathrm{O}$ and $\mathrm{M}-\mathrm{CH}_{2} \mathrm{O}-132$ also indicated the presence of the same system as 5 . Thus 7 was a 3hydroxymethyl derivative of 9 . The MS data of the diacetate of 7 also supported this structure.

\section{Routes of formation}

Under the condition employed, 3-hydroxymethyloxindole (1) and 3-methyleneoxindole (2) were the main products, and indolyl-3aldehyde (4), 3-acetoxyindole (3) and six of the dimeric and trimeric adducts were the minor ones, among those isolated and charac- terized. Figure 4 showes a possible formation route of these products.

The first product of the HRP-catalyzed oxidation of IAA appears to be an IAA free radical (I) cited by Hinman and Lang's or its equivalent, from a consideration of the formation mechanism of $\mathbf{3}$ and six of the adducts, as follows. When the radical I rearranges with the cleavage between the C-3 carbon and the side chain as shown in Route a, 3 will be produced. When decarboxylation occurs at this stage as shown in Route $b, 3$-methyleneindolenine (II), which have been found as a reaction product of IAA in a corn IAA oxidase system, ${ }^{3)}$ will be produced. Also, when a Michael type addition of 1 occurs to II, the dimer 5 will be produced, and subsequently will lead to 6 via a reverse aldole type reaction. The formation of the adducts, 7, 8, and 9, can also be speculated by the reaction mechanism similar to that of 5 . When the $\mathrm{C}-2$ carbon of the indole ring of 5, IAA, or 6 couples with II, each corresponding dimer or trimer will be produced. The product $\mathbf{1 0}$ will be formed through the pathway proposed in the corn IAA oxidase system $^{3}$; 3-hydroxymethylindole (III), which will be formed reversibly by hydration of II, couples with II, and the resulting adduct IV is then converted into $\mathbf{1 0}$ by release of formaldehyde. In our scheme speculated here, the most significant point is that the free

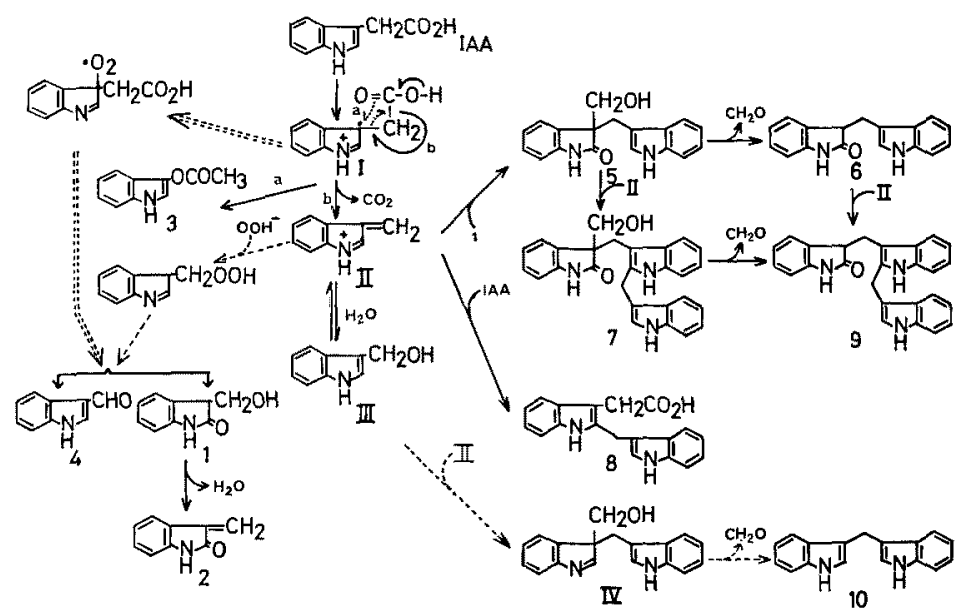

FIG. 4. A Possible Formation Route of Products. 
radical $I$ or its equivalent could give rise to the two routes a and $b$, rather than the conventionally accepted route of the oxygen addition.

Among ten products isolated, each of 5 and 7 has an asymmetric carbon, which, once formed, cannot racemize through enolization at the C-3 of the oxindoles. Both compounds, however, were optically inactive. This fact suggested that these two adducts are formed nonenzymatically. The same logic may be given for the other adducts, when referred to their possible formation route shown in Fig. 4. On the other hand, the hydration process from 1 to $\mathbf{2}$ have been already proved to be a postenzymatic step. ${ }^{2)}$ As to this problem, a mechanism in which IAA oxidation by HRP occurs mainly through a free radical chain reaction has been also proposed, ${ }^{10)}$ on the basis of the spectroscopic observation of the enzymatic reaction. Therefore, the determination of the reaction process where HRP enzyme participate directly, along with that of the forming pathway of 1 and 4 , are remaining problems to be clarified. This is under current investigation in parallel with that of photooxidation of IAA.

\section{EXPERIMENTAL}

Melting points were uncorrected. UV spectra were determined with a Shimazu UV 200 spectrometer. IR spectra were measured with a JASCO IRA-1, PMR spectra with Varian HA-100 or JEOL JNM-PMX 60 instruments using TMS as an internal standard, and MS spectra with Hitachi RMU-6MG (20 eV, low resolution MS spectra) and JEOL-01SG-2 $(70 \mathrm{eV}$, high resolution MS spectra) spectrometers using a direct inlet. ORD and optical rotations were recorded with a JASCO J-20 spectrometer.

Pre-coated silica gel $F_{264}$ plates $(0.25 \mathrm{~mm}$ thickness $)$ for TLC and silica gel $P_{254}$ for preparative TLC $(0.5 \mathrm{~mm}$ thickness) were used.

\section{HRP oxidation}

a) Time course experiment. The reaction mixture composed of IAA potassium salt $(4.2 \mathrm{mg})$ and HRP (1.0 mg; Boehringer Maunheim Ltd., Reinheitzahl: 0.6) in $100 \mathrm{ml}$ of $5 \times 10^{-2} \mathrm{M}$ acetate buffer $(\mathrm{pH} 5.0)$ was stirred magnetically at $25^{\circ} \mathrm{C}$. Two $\mathrm{ml}$ of the reaction mixture was taken out at zero min and after 10,15 , and $30 \mathrm{~min}$ of incubation and extracted with $3 \mathrm{ml}$ of $\mathrm{Et}_{2} \mathrm{O}$.
The UV spectra of each $\mathrm{Et}_{2} \mathrm{O}$ layer were measured in quartz cuvets of $1-\mathrm{cm}$ light path.

b) Preparative scale reaction. Three liters of the reaction mixture including $128 \mathrm{mg}$ of IAA potassium salt was incubated for $30 \mathrm{~min}$ in similar manner. The reaction mixture was extracted two times with EtOAc (2, 1 liters, each), which were combined and washed with $\mathrm{H}_{2} \mathrm{O}$. The extract, after drying over anhyd. $\mathrm{Na}_{2} \mathrm{SO}_{4}$, was concentrated in vacuo. The combined concentrated extract of the four baches was subjected immediately to gel filtration on Sephadex LH 20 (1.9x $90 \mathrm{~cm}$ ) with $\mathrm{MeOH}$. The eluate was examined by TLC using $\mathrm{CHCl}_{3}-$ EtOAc- $\mathrm{HCO}_{2} \mathrm{H}$ (35:55: 10, Solvent a) and grouped into 8 fractions; A (80 mg), B (32 $\mathrm{mg})$, $\mathrm{C}(50 \mathrm{mg}), \mathrm{D}(40 \mathrm{mg}), \mathrm{E}(10.5 \mathrm{mg}), \mathrm{F}(14.7 \mathrm{mg}), \mathrm{G}$ (22.9 $\mathrm{mg})$, and $H(9.2 \mathrm{mg})$. Among these, $C$ fraction was a mixture of 3,4 , and 5 and the unconsumed IAA. The other fractions were consisted of almost one component on TLC.

\section{3-Hydroxymethyloxindole (1)}

Fraction A was crystalized rapidly from EtOH to afford pale yellow fine needles $(1,45 \mathrm{mg})$; mp 126 $129^{\circ} \mathrm{C}$. Attempts to purify fraction A by silica gel TLC (Solvent a) or slower crystalization than one day at $-20^{\circ} \mathrm{C}$ in EtOH were unsuccessful, being accompanied with small amounts of 2 derived from 1 . $[\alpha]_{D}^{20} \pm 0,0$ ( $c=1.0, \mathrm{MeOH}) ; \mathrm{MS} m / e$ (rel. int.): $163\left(\mathrm{M}^{+}, 18\right), 145$ $\left(\mathrm{M}-\mathrm{H}_{2} \mathrm{O}, 34\right), 133\left(\mathrm{M}-\mathrm{CH}_{2} \mathrm{O}, 100\right), 117$ (44); UV $\lambda_{\operatorname{ma}}^{\mathrm{MeO}} \mathrm{nm}(\varepsilon): 280(1150), 249(7100), 207(23000) ; \mathrm{PMR}$ $\left(\mathrm{CD}_{3} \mathrm{SOCD}_{3}\right.$, Fig. 3) $\delta: 3.42(1 \mathrm{H}, \mathrm{t}, J=5 \mathrm{~Hz}), 3.64 \sim$ $4.06(2 \mathrm{H}, \mathrm{m}), 4.80(1 \mathrm{H}, \mathrm{t}, J=5 \mathrm{~Hz}, \mathrm{OH}), 6.75 \sim 7.32$ $(4 \mathrm{H}, \mathrm{m}) ; \operatorname{IR} \nu_{\max }^{\mathrm{KBr}} \mathrm{cm}^{-1}: 3450,3200,1690$.

\section{3-Methyleneoxindole (2)}

Fraction B, which was almost homogeneous with TLC (Solvent a), gave several spots at lower $R f$ than that of 2 together with $\mathrm{MeOH}$ insoluble substances. The yield and the absorption intensity of the UV spectrum were estimated on the basis of the amount of pale yellow solid obtained by removal of the solvent. UV $\lambda_{\max }^{\mathrm{MeOH}} \mathrm{nm}(\varepsilon): 278(3800), 254(23000), 247$ (35000); MS mle (rel. int.): $145\left(\mathrm{M}^{+}, 100\right), 130(78), 117(32)$, $90(17)$, and $290(43), 162(9), 161(9), 176(15), 158(7)$ due to the dimers of 2 .

3-Acetoxyindole (3), indolyl-3-aldehyde (4), and 3-hydroxymethyl-3-(indol-3-ylmethyl)oxindole (5)

Fraction $\mathrm{C}$ was purified by preparative TLC (Solvent a). The respective band at $R f 0.69,0.55,0.49$, and 0.44 regions which were visible under UV light was eluted with MeOH followed by gel filtration on Sephadex LH $20(0.7 \times 20 \mathrm{~cm})$ with $\mathrm{MeOH}$, affording $3(5.0 \mathrm{mg})$, IAA (7.1 $\mathrm{mg}), \mathbf{4}(8.0 \mathrm{mg})$, and $5(8.0 \mathrm{mg})$.

3, plates (EtOH), mp $127 \sim 130^{\circ} \mathrm{C}$; MS m/e (rel. int.): 
$175\left(\mathrm{M}^{+}, 23\right), 133(100)$; UV $\lambda_{\max }^{\mathrm{MeOH}} \mathrm{nm}(\varepsilon): 289(3600)$, 280 (4300), 220 (22900); PMR (CD $\left.{ }_{3} \mathrm{OD}\right) \delta: 2.30(3 \mathrm{H}, \mathrm{s})$, $7.00 \sim 7.50(5 \mathrm{H}, \mathrm{m}) ; \mathrm{IR} \nu_{\max }^{\mathrm{KBr}} \mathrm{cm}^{-1}: 3350,1750$.

4, plates $\left(\mathrm{H}_{2} \mathrm{O}\right)$, mp $195 \sim 199^{\circ} \mathrm{C}$; MS $m / e$ (rel. int.): $145\left(\mathrm{M}^{+}, 83\right), 144(100), 116(34), 89(29)$; UV $\lambda_{\max }^{\mathrm{MeOH}}$ $\mathrm{nm}(\hat{\varepsilon}): 294$ (8000), $260(7600), 242$ (9300), 212 (17000); $\mathrm{PMR}\left(\mathrm{CD}_{3} \mathrm{COCD}_{\S}\right) \delta: 7.20 \sim 8.30(5 \mathrm{H}, \mathrm{m}), 10.02(1 \mathrm{H}$, s), $11.10(1 \mathrm{H}, \mathrm{bs}, \mathrm{NH})$.

5, prisms (MeOH), mp $178 \sim 181^{\circ} \mathrm{C}$ (dec.); $[\alpha]_{\mathrm{D}}^{20} \pm 0.0$ $(c=0.67, \mathrm{MeOH}) ; \mathrm{MS} m / e$ (rel. int.): $292.1220\left(\mathrm{M}^{+}\right.$, $\left.\mathrm{C}_{18} \mathrm{H}_{18} \mathrm{O}_{2} \mathrm{~N}_{2}, 3\right), 262.1116\left(\mathrm{M}-\mathrm{CH}_{2} \mathrm{O}, 10\right), 130.0655$ $\left(\mathrm{C}_{9} \mathrm{H}_{8} \mathrm{~N}, 100\right), 116.0491\left(\mathrm{C}_{8} \mathrm{H}_{6} \mathrm{~N}, 12\right)$; UV $\lambda_{\max }^{\mathrm{MeOH}} \mathrm{nm}(\varepsilon)$ : $290(4400), 282(5100), 250$ (8000), 223 (25600), 210 (37000); PMR $\left(\mathrm{CD}_{3} \mathrm{SOCD}_{3}\right) \delta: 3.15(2 \mathrm{H}, \mathrm{ABq} . J=$ $14 \mathrm{~Hz}), 3.78(2 \mathrm{H}, \mathrm{s}), 6.50 \sim 7.50(9 \mathrm{H}, \mathrm{m}), 10.00$ and 10.62 (each $1 \mathrm{H}, \mathrm{bs}, \mathrm{NH}$ ); IR $\nu_{\max }^{\mathrm{KBr}} \mathrm{cm}^{-1}: 3400,1700.5$ (7.0 mg) was acetylated with $\mathrm{Ac}_{2} \mathrm{O}$ and pyridine (each $0.2 \mathrm{ml}$ ) at room temperature. Removal of the excess of the reagents afforded the diacetate of $5, R f 0.71$ with Solvent a. MS $m / e$ (rel. int.): $376\left(\mathrm{M}^{+}, 2\right), 172$ (3), $145(5), 130(100), 117(3)$; UV $\lambda_{\max }^{\text {MeOH }} \mathrm{nm}: 290,280$, 275, 219; PMR $\left(\mathrm{CD}_{3} \mathrm{SOCD}_{3}\right) \delta: 1.80(3 \mathrm{H}, \mathrm{s}), 2.28(3 \mathrm{H}$, s), $3.35(2 \mathrm{H}, \mathrm{bs}), 4.59(2 \mathrm{H}, \mathrm{ABq}, J=10 \mathrm{~Hz}), 6.50 \sim 7.90$ $(9 \mathrm{H}, \mathrm{m}), 10.80(1 \mathrm{H}, \mathrm{bs}, \mathrm{NH})$.

\section{3-(Indol-3-ylmethyl)oxindole (6)}

Fraction $\mathrm{D}$ afforded pale red amorphous powder 6 ( $8.0 \mathrm{mg})$ by preparative TLC ( $\mathrm{MeOH}-\mathrm{CHCl}_{3}$ (7: 93), Solvent $b)$ and gel filtration $(\mathrm{MeOH}) . \quad[\alpha]_{\mathrm{D}}^{20} \pm 0.0(c=$ $2.2, \mathrm{MeOH})$; MS $m / e$ (rel. int.): $262\left(\mathrm{M}^{+}, 10\right), 130$ (100); UV $\lambda_{\max }^{\mathrm{MeOH}} \mathrm{nm}(\varepsilon): 290(4900), 282(6000), 250(9000)$, 220 (35000), 217 (37000); PMR ( $\left.\mathrm{CD}_{3} \mathrm{SOCD}_{3}\right) \delta: 3.10$, 3.45 , and 3.78 (each $1 \mathrm{H}$, ABX type of splitting, $J=15$, 8 , and $5 \mathrm{~Hz}), 6.70 \sim 7.60(9 \mathrm{H}, \mathrm{m}), 10.24$ and 10.72 (each $1 \mathrm{H}$, bs, $\mathrm{NH}$ ); IR $\nu_{\max }^{\mathrm{KBr}} \mathrm{cm}^{-1}: 3400,1700.6$ $(22.1 \mathrm{mg})$ was treated with an excess of lithium aluminum hydride $(10 \mathrm{mg})$ in dry tetrahydrofuran $(3 \mathrm{ml})$ with refluxing for $30 \mathrm{~min}$. After adding EtOAc saturated with $\mathrm{H}_{2} \mathrm{O}(10 \mathrm{ml})$ to the reaction mixture, the EtOAc extract was concentrated and passed through Sephadex LH 20 with $\mathrm{MeOH}$ to afford a main product $(4.7 \mathrm{mg})$, identified (PMR, UV, MS, and $R f$ values on TLC) as 10.

\section{3-Hydroxymethyl-3-[2-(indol-3-ylmethyl)indol-3-yl- methyl loxindole (7)}

Fraction $\mathrm{E}$ was purified by preparative TLC (Solvent b), affording pale red amorphous powder $7(4.2 \mathrm{mg})$. MS $m / e$ (rel. int.): $421\left(\mathrm{M}^{+}, 0.1\right), 391(10), 259(100)$, 133, 130, 117; UV $\lambda_{\max }^{\mathrm{MeOH}} \mathrm{nm}(\epsilon): 292(12500), 284$ (14500), 276 (13500), $260(13000), 225(61000), 215$ (56000); PMR $\left(\mathrm{CD}_{3} \mathrm{COCD}_{3}\right) \delta: 3.40(2 \mathrm{H}, \mathrm{ABq}, J=$ $14 \mathrm{~Hz}$ ), 4.00 and 4.10 (each $2 \mathrm{H}, \mathrm{s}), 6.70 \sim 7.50(17 \mathrm{H}, \mathrm{m})$, $9.10,9.40$, and 9.90 (each $1 \mathrm{H}$, bs, $\mathrm{NH}) . \quad 7(1.2 \mathrm{mg})$ was acetylated in similar manner to afford the diacetate of 7, Rf 0.68 with Solvent a. MS $m / e$ (rel. int.): $505\left(\mathrm{M}^{+}\right.$,
$0.5), 259(100), 145(17), 130(5), 117(7)$.

\section{2-(Indol-3-ylmethyl)indolyl-3-acetic acid (8)}

Fraction F was purified by preparative TLC (Solvent b), affording a pale red solid $8(4.0 \mathrm{mg})$. MS $m / e$ (rel, int.): $304.1217\left(\mathrm{M}^{+}, \mathrm{C}_{10} \mathrm{H}_{10} \mathrm{O}_{2} \mathrm{~N}_{2}, 100\right), 259.1227$ (M$\left.\mathrm{CO}_{2} \mathrm{H}, 43\right), 245.1083\left(\mathrm{M}-\mathrm{CH}_{2} \mathrm{CO}_{2} \mathrm{H}, 93\right), 187.0631$ (M-117, 12), $130.0634\left(\mathrm{C}_{8} \mathrm{H}_{8} \mathrm{~N}, 12\right), 117.0601\left(\mathrm{C}_{8} \mathrm{H}_{7} \mathrm{~N}\right.$, 6); UV $\lambda_{\max }^{\mathrm{MeOH}} \mathrm{nm}(\varepsilon): 290$ (13200), 282 (15200), 224 (31000); PMR $\left(\mathrm{CD}_{3} \mathrm{OOCD}_{3}\right) \delta: 3.74(2 \mathrm{H}, \mathrm{s}), 4.25(2 \mathrm{H}$, s), $6.90 \sim 7.60(9 \mathrm{H}, \mathrm{m}), 9.56$ and 9.95 (each $1 \mathrm{H}, \mathrm{bs}, \mathrm{NH})$; IR $\nu_{\max }^{\mathrm{KBr}} \mathrm{cm}^{-1}: 3400,1700 . \quad 8(0.7 \mathrm{mg})$ was treated with etherial diazomethane at $0^{\circ} \mathrm{C}$ for $30 \mathrm{~min}$ to afford the methyl ester of $8, \mathrm{MS} m / e$ (rel. int.): $318\left(\mathrm{M}^{+}, 93\right), 259$ $245(100), 201(6), 130(7), 117(2) .8(0.7 \mathrm{mg})$ was treated with an excess of lithium aluminum hydride $(3 \mathrm{mg})$ in dry tetrahydrofuran $(3 \mathrm{ml})$ at room temperature for $1 \mathrm{hr}$ to afford the reduction product of 8 , MS m/e (rel. int.): $290\left(\mathrm{M}^{+}, 54\right), 259(100), 245$ (5), $130(10)$.

\section{3-[(2-Indol-3-ylmethyl )indol-3-ylmethyl ]oxindole (9)}

Fraction $G$ was also purified by preparative TLC (Solvent b), affording a pale red solid $9(9.1 \mathrm{mg})$. $[\alpha]_{\mathrm{D}}^{20} \pm 0.0(c=0.80, \mathrm{MeOH}) ; \mathrm{MS} m / e$ (rel. int.): 391.1718 $\left(\mathrm{M}^{+}, \mathrm{C}_{28} \mathrm{H}_{21} \mathrm{ON}_{3}, 9\right)$, $259.1219\left(\mathrm{M}-\mathrm{C}_{8} \mathrm{H}_{6} \mathrm{ON}, 100\right)$, $260.1314\left(\mathrm{M}-\mathrm{C}_{8} \mathrm{H}_{5} \mathrm{ON}, 26\right), 133,130,117$ (10); UV $\lambda_{\max }^{\mathrm{MeO}} \mathrm{nm}(\varepsilon): 290(12300), 282(14200), 260(13200)$, 250(14000), 225(56300), 215(58300); PMR( $\left.\mathrm{CD}_{3} \mathrm{COCD}_{3}\right)$ $\delta: 3.14,3.64$, and 3.82 (each $1 \mathrm{H}, \mathrm{ABX}$ type of splitting, $J=14,9$, and $4 \mathrm{~Hz}), 4.14(2 \mathrm{H}, \mathrm{s}), 6.70 \sim 7.60(13 \mathrm{H}, \mathrm{m})$, $9.30,9.70$, and 10.00 (each $1 \mathrm{H}, \mathrm{bs}, \mathrm{NH}) ; \mathrm{IR} \nu_{\mathrm{max}}^{\mathrm{KBr}} \mathrm{cm}^{-1}$ : $3400,1700$.

\section{3,3-Diindolylmethane (10)}

Fraction $\mathrm{H}$ was purified similarly by preparative TLC (Solvent b) to afford $\mathbf{1 0}(5.4 \mathrm{mg})$, pale yellow plates (MeOH), mp $162 \sim 163^{\circ} \mathrm{C}$; MS $m / e$ (rel. int.): $246\left(\mathrm{M}^{+}\right.$, 100), 245 (75), $130(10), 117(5)$; PMR $\left(\mathrm{CD}_{3} \mathrm{COCD}_{3}\right)$ $\delta: 4.22(2 \mathrm{H}, \mathrm{s}), 6.90 \sim 7.65(10 \mathrm{H}, \mathrm{m}), 9.90(2 \mathrm{H}, \mathrm{bs}, \mathrm{NH})$; UV $\lambda_{\text {max }}^{\mathrm{MeOH}} \mathrm{nm}(\varepsilon): 290(12600), 283(14500), 275(14000)$, 225 (78500); IR $\nu_{\max }^{\mathrm{KB}} \mathrm{cm}^{-1}: 3400$.

Acknowledgement. The authors thank Mr. H. Hattori of Nagoya University for high resolution MS measurements, Mr. J. Uzawa and Mrs. T. Chijimatsu for PMR measurements, and Dr. K. Tsuji for reviewing the manuscript. This work was supported in part by a grant from Science and Technology Agency of Japan.

\section{REFERENCES}

1) E. A. Schneider and F. Wightman, Amn. Rev. 
Plant Physiol., 25, 487 (1974) and references therein.

2) R. L. Hinman and J. Lang, Biochemistry, 4, 144 (1965).

3) J. N. BeMiller and W. Colilla, Phytochemistry, 11, 3393 (1972).

4) H. Kinashi, Y. Suzuki, S. Takeuchi and A. Kawarada, Agric. Biol. Chem., 40, 2465 (1976); Y. Suzuki, H. Kinashi, S. Takeuchi and A. Kawarada, Phytochemistry, 16, 635 (1977).

5) Unpublished result.
6) D. J. Siehr, J. Am. Chem. Soc., 83, 2401 (1961).

7) R. L. Hinman, C. Bauman and J. Lang, Biochem. Biophys. Res. Commun., 5, 250 (1961).

8) D. Racusen, Arch. Biochem. Biophys., 58, 508 (1955); R. E. Stutz, Plant Physiol., 33, 207 (1958).

9) T. T. Fukuyama and H. S. Moyed, J. Biol. Chem., 239, 2392 (1964); V. Tuli and H. S. Moyed, Plant Physiol., 42, 425 (1967); H. J. Hope and L. Ordin, Phytochemistry, 10, 1551 (1971).

10) L. R. Fox, W. K. Purves and H. I. Nakada, Biochemistry, 4, 2754 (1965). 